\title{
Peran Perempuan dalam Membangun Kerukunan Umat Beragama : Studi Komparatif Indonesia dan Malaysia
}

\author{
Daimah, S.Pd.I \\ UIN Sunan Kalijaga Yogyakarta Indonesia \\ Email: sholihahdaimah@gmail.com
}

\begin{abstract}
Empowering women in various dimensions of religious social life has received global attention among women observers and observers of development issues. In building religious harmony, women can play a role in two sectors, namely the role of women in the family and the role of women in social life. In the family, the role of women as a wife and at the same time as a mother becomes an example in acting in the family. Likewise with the role of women in social life, women are able to contribute to the avodication of peace in creating religious harmony.
\end{abstract}

Keywords: The Role of Women, Harmony of Embrace The Religion, Indonesia, Malaysia

\section{Pendahuluan}

Dalam diskursus kehidupan masyarakat, kaum perempuan ditempatkan sebagai the second class dalam struktur sosial. Fakta ini didasarkan atas suatu perspektif yang menganut budaya patriarki - sebuah budaya yang mengindentikkan perempuan sebatas di dapur. Stereotip perempuan yang pasif, emosional dan tidak mandiri telah menjadi citra baku yang sulit diubah. Hal tersebut menunjukkan adanya ketimpangan atau bias gender yang sesungguhnya merugikan kaum perempuan. Bias gender berimplikasi pada perdebatan tentang peran kaum perempuan. Banyak masyarakat menilai bahwa perempuan semestinya hanya berperan dalam ranah domestik (rumah tangga) saja. Akan tetapi, seiring perkembangan zaman kini perempuan lebih berani tampil ke publik untuk juga berpartisipasi dan memberikan kontribusinya dalam segala bidang baik politik, budaya, sosial, ekonomi ataupun pendidikan. Perubahan zaman telah membuat perempuan tidak hanya mampu mengemban urusan domestik, namun mereka juga mampu berkontribusi lebih untuk kemajuan bangsa dan negara.

Dalam perspektif religiusitas misalnya, perempuan mempunyai peran yang signifikan dalam menciptakan dan merawat kehidupan yang rukun, aman dan damai di masyarakat. Hal tersebut didasarkan atas statemen UNESCO yang menyatakan bahwa perempuan memiliki peran signifikan dalam gerakan perdamaian dunia. Penelitian menunjukkan bahwa 


\section{Daimah}

melibatkan perempuan dalam peacebuilding meningkatkan kemungkinan bahwa kekerasan akan berakhir $24 \%$. Peran perempuan sebagai istri, ibu dan juga pendidik anak-anak sangat penting dalam menyemai pendidikan dan wacana agama yang terbuka. Sifat-sifat feminin, dan juga spiritualitas, yang tentu dipunyai kebanyakan perempuan diakui banyak kalangan menjadi salah satu faktor penting dalam mengantisipasi konflik dan kekerasan atas nama apapun. Sifat feminitas merupakan hal yang niscaya dalam menciptakan perdamaian antarsesama. Oleh karena itu, peran perempuan dalam mengantisipasi konflik dan mencegah kekerasan harus terus dikembangkan dan ditingkatkan baik kualitas maupun kuantitasnya, termasuk untuk para perempuan di Indonesia dan juga Malaysia sebagai negara plural.

Dalam artikel ini akan diuraikan tentang bagaimana peran domestik dan publik perempuan dalam mebangun kerukunan umat beragama perspektif Indonesia dan Malaysia.

\section{Konsep Kerukunan Umat Beragama}

Dalam pengertian sehari-hari kata rukun dan kerukunan adalah damai dan perdamaian. Dengan demikian jelas bahwa kata kerukunan hanya dipergunakan dan berlaku dalam dunia pergaulan/sosial. Kerukunan antar umat beragama adalah cara atau sarana untuk mempertemukan, mengatur hubungan luar antara orang yang tidak seagama atau antar golongan umat beragama dalam kehidupan sosial kemasyarakatan (Ibnu Rusydi, Jurnal AlAfkar Vol. 1 No. 1 Januari 2019: 172). Lebih lanjut, dalam Peraturan Bersama Menteri Agama dan Menteri Dalam Negeri (PMB) No 8 dan 9 tahun 2006 pasal 1, menyebutkan bahwa kerukunan umat beragama merupakan keadaan hubungan sesama umat beragama dilandasi toleransi, saling pengertian, saling menghormati, menghargai kesetaraan dalam pengalaman ajaran agamanya dan kerjasama dalam kehidupan bermasyarakat, berbangsa dan bernegara di dalam Negera Kesatuan Republik Indonesia berdasarkan Pancasila dan Undang-undang Dasar Negara Republik Indonesia Tahun 1945 (Peraturan Bersama Menteri Agama dan Menteri Dalam Negeri (PMB) No 8 dan 9 tahun 2006 pasal 1)

Pada mulanya istilah kerukunan umat beragama telah lama menjadi slogan pemerintah dalam mengatur masyarakat Indonesia yang majemuk. Peremintah sejak awal Orde Baru telah mengeluarkan beberapa kebijakan kerukunan umat beragama di tengah-tengah masyarakat. Dalam pidatonya Menteri Agama, K.H.M Dachlan dalam acara Pembukaan Musyawarah Antar Agama 30 November 1967:

"Adanya kerukunan antara golongan beragama adalah syarat mutlak bagi terwujudnya stabilitas politik dan ekonomi yang program Kabinet Ampera. Oleh karena itu, 
kami mengharapkan sungguh adanya kerjasama antara Pemerintah dan masyarakat beragama untuk menciptakan "iklim kerukunan beragama" ini, sehingga tuntutan hati nurani rakyat dan cita-cita kita bersama ingin mewujudkan masyarakat yang adil dan makmur yang dilindungi Tuhan Yang Maha Esa itu benar-benar dapat terwujud”.

Berdasarkan pernyataan K.H.M Dachlan di atas, kemudian disandingkan dengan konsep Menteri Agama lainnya untuk membuat konsep yang mengatakan bahwa "Kerukunan hidup beragama adalah suatu kondisi sosial di mana semua golongan agama bisa hidup bersamasama tanpa mengurangi hak dasar masing-masing untuk melaksanakan kewajiban agamanya. Masing-masing hidup sebagai pemeluk agama yang baik, dalam keadaan rukun dan damai”.9 Hayat, dalam Mengelola Kemajemukan Umat Beragama, menyebutkan setidaknya ada tiga prinsip dasar dalam konsep kerukunan yaitu, prinsip mengakui (to accept), menghargai (to respect) eksistensi agama lain dan bekerjasama (to cooperate). Selain itu, dalam harmonisasi kehidupan beragama, Hayat menyatakan bahwa pendekatan modal sosial (social capital) dapat mengatasi persoalan teologis dan relasional di kalangan umat beragama (Ihsan Ali Fauzi, dkk, 2017: 126).

Hasbullah Bakri, dalam bukunya Pendekatan Dunia Islam dan Dunia Kristen, mengatakan bahwa kerukunan beragama dalam pengertian praktis dapat diartikan ko-eksistensi secara damai antara satu atau lebih golongan agama dalam kehidupan beragama. Sementara penulis lainnya, Amir Syarifuddin, mengatakan, "kerukunan hidup antar-umat beragama adalah suatu cara untuk mempertemukan, atau mengatur hubungan luar antara orang-orang berlainan agama dalam proses bermasyarakat, jadi kerukunan antar-umat beragama tidak berarti menyatukan agama-agama yang berbeda" (Ihsan Ali Fauzi, dkk, 2017: 127).

Sementara, istilah "kerukunan" dalam Kamus Besar Bahasa Indonesia yang diterbitkan oleh Departemen Pendidikan dan Kebudayaan, diartikan sebagai "hidup bersama dalam masyarakat dengan "kesatuan hati" dan "bersepakat" untuk tidak menciptakan perselisihan dan pertengkaran". Kerukunan adalah istilah yang dipenuhi oleh muatan makna "baik" dan "damai". Intinya, hidup bersama dalam masyarakat dengan "kesatuan hati" dan "kesepakatan" untuk tidak menciptakan perselisihan dan pertengkaran (Ibnu Rusydi, Jurnal Al-Afkar Vol. 1 No. 1 Januari 2019: 172). Dengan demikian, dari beberapa pendapat diatas dapat disimpulkan bahwa Kerukunan Hidup Beragama berarti perihal hidup rukun, yaitu hidup dalam suasana baik dan damai, tidak bertengkar, bersatu hati dan bersepakat antarumat yang berbeda-beda agamanya, atau secara resmi, konsep kerukunan umat beragama mencakup 3 kerukunan, yaitu kerukunan intern umat beragama, kerukunan antarumat yang berbeda-beda agama, dan 


\section{Daimah}

kerukunan antara (pemuka) umat beragama dengan Pemerintah.

\section{Problem Intoleransi Antar Umat Beragama}

Lewis A Coser dalam bukunya The Functions of Social Conflict (1956 : 33-128) menjelaskan bahwa suatu konflik sosial, salah satunya adalah konflik keagamaan, biasanya terjadi karena bertemunya empat elemen utama dalam waktu yang bersamaan. Keempat elemen tersebut ialah facilitating contexts (konteks pendukung), core (roots) of conflict (akar konflik), fuce factor (sumbu), dan triggering factors (pemicu). Dalam suatu konflik sosial bernuansa agama, konteks pendukung (facilitating context) itu berupa pola pekerjaan atau pemukiman yang terpisah berdasarkan garis keagamaan antara berbagai kelompok yang akan terlibat konflik, atau kompetisi perkembangan demografi keagamaan, atau urbanisasi yang berdampak menggusur penduduk lokal (asli), dan lain-lain.

Akar konflik (core of conflict), biasanya adalah suatu tingkatan penderitaan sosial atau marginalisasi sosial yang tidak ditolelir lagi dalam perebutan sumber-sumber daya (resources) maupun kekuasaan (power). Sumbu (fuce factor) biasanya juga sudah ada disana, tetapi tidak dengan sendirinya menyala menjadi konflik jika tidak tersulut atau disulut. Sumbu konflik bisa berupa sentimen suku, ras, keagamaan dan lain-lain. Sedangkan pemicu (triggering factors) adalah peristiwa-peristiwa atau momentum dimana semua elemen diatas diakumulasikan untuk melahirkan konflik sosial. Momentum itu biasanya hanya berbentuk pertengkaran kecil antara dua individu mengenai sesuatu hal yang amat remeh atau jauh dari akar konflik, tertapi berfungsi sebagai pembenar bagi dimulainya suatu konflik yang berskala besar.

Penyebab kerawanan tersebut sebagaimana yang diuraikan oleh Puslitbang Kehidupan Keagamaan Badan Litbang dan Diklat Departemen Agama (2008 : 269-270) antara lain sebagai berikut:

1) Pendirian Rumah Ibadah. Dalam hal ini tempat ibadah yang didirikan tanpa mempertimbangkan situasi dan kondisi lingkungan umat beragama setempat sering menciptakan ketidakharmonisan umat beragama yang dapat menimbulkan konflik antar umat beragama.

Penyiaran Agama. Dalam hal ini penyiaran agama baik secara lisan, melalui media cetak seperti brosur, pamflet, selebaran dan sebagainya, maupun media elektronika, serta media yang lain yang dapat menimbulkan kerawanan dibidang kerukunan hidup umat beragama, lebih-lebih yang ditujukan kepada orang yang telah memeluk agama lain.

130 || Jurnal eL - Tarbawi

Volume XI, No. 1, 2018 
3) Bantuan Luar Negeri. Dalam hal ini bantuan luar negeri untuk pengembangan dan penyebaran suatu agama, baik berupa bantuan materiil/finansial ataupun bantuan ahli keagamaan, bila tidak mengikuti peraturan yang ada, dapat menimbulkan ketidakharmoisan dalam kerukunan hidup umat beragama, baik intern umat beragama yang dibantu maupun antar umat beragama.

4) Perkawinan Beda Agama. Dalam hal ini perkawinan yang dilakukan oleh pasangan yang berbeda agama, walaupun pada mulanya bersifat pribadi dan konflik antar keluarga, sering mengganggu keharmonisan dan kerukunan hidup umat beragama, terlebih apabila sampai kepada akibat hukum dan perkawinan tersebut, atau terhadap harta benda perkawinan, warisan dan sebagainya.

5) Perayaan Hari Besar Keagamaan. Dalam hal ini penyelenggaraan perayaan hari besar keagamaan yang kurang mempertimbangkan kondisi dan situasi serta lokasi dimana perayaan tersebut diselenggarakan dapat menyebabkan timbulnya kerawanan dibidang kerukunan hidup beragama.

6) Penodaan Agama. Dalam hal ini perbuatan yang bersifat melecehkan atau menodai ajaran dan keyakinan suatu agama tertentu dilakukan oleh seseorang atau sekelompok orang dapat menyebabkan timbulnya kerawanan dibidang kerukunan hidup umat beragama.

7) Kegiatan Aliran Sempalan. Dalam hal ini kegiatan yang dilakukan oleh seseorang atau sekelompok orang yang didasarkan pada keyakinan tertentu secara menyimpang dari ajaran agama yang bersangkutan dan menimbulkan keresahan terhadap kehidupan beragama, dapat menyebabkan timbulnya kerawanan di bidang kerukunan hidup beragama.

8) Aspek Non Agama yang Mempengaruhi. Dalam hal ini aspek-aspek non agama yang dapat mempengaruhi kerukunan hidup umat beragama antara lain : kepadatan penduduk, penyusupan ideologi dan politik berhaluan keras yang berskala regional maupun internasional yang masuk ke Indonesia melalui kegiatan agama.

Iqnas Kleden juga menambahkan bahwa bentuk kehidupan agama yang tertutup atau fanatik juga merupakan sumber konflik yang mengancam keutuhan masyarakat. Potensi atau sumber konflik yang ada juga berkembang menjadi konflik apabila terjadi persaingan yang bersifat 


\section{Daimah}

emosional. Corak emosional lebih banyak banyak muncul pada komunitas yang ekslusif terbentuk sebagai akibat terpisahnya kegiatan sosial antar kelompok agama yang ada, sehingga menimbulkan kecenderungan untuk menutup diri dan saling berprasangka antar kelompok agama tersebut (Imron Rosyidi, 2009: 45).

Dengan demikian sesungguhnya sumber konflik itu sangat konpleks dan saling terkait satu sama lainnya, sehingga memperkuat munculnya suatu konflik yang bernuansa keagamaan. Konflik keagamaan yang merupakan suatu permasalahan yang berkaitan dengan agama tersebut, sesungguhnya bukan karena agamanya yang gagal dalam mewujudkan toleransi, perdamaian dan kesejahteraan di masyarakat, tetapi para pemeluknyalah yang gagal dalam memahami dan memaknai agama yang dianutnya selama ini.

\section{Dinamika Kerukunan Antar Umat Beragama di Indonesia}

Penduduk Indonesia mengandung 370 suku bangsa dan lebih 67 bahasa daerah. Sejumlah etnis Melayu, Cina, Arab, India, dan Negrito berkumpul dalam pagar kesatuan politik Republik Indonesia (RI). Indonesia juga mengandung keaneragaman agama, yaitu Islam, Kristen Protestan, Katolik, Budha, dan Hindu. Jenis kepercayaan lain, seperti Kong $\mathrm{Hu}$ Chu, Kejawen, dan kepercayaan masyarakat-masyarakat terasing seperti Badui, Tengger, Semain, Dayak dan sejumlah suku di Irian Jaya (Nurcholis Madjid, 2001: 95). Keberagama di Indonesia memegang peranan penting dalam kehidupan masyarakat. Hal ini dinyatakan dalam ideologi bangsa Indonesia yaitu Pancasila pada sila pertama "Ketuhanan Yang Maha Esa". Sejumlah agama di Indonesia berpengaruh secara kolektif terhadap politik, ekonomi, dan budaya. Dalam UUD 1945 dinyatakan bahwa "tiap-tiap penduduk diberikan kebebasan untuk memilih dan mempraktikkan kepercayaannya dan menjamin semuanya akan kebebasan untuk menyembah, menurut agama atau kepercayaannya”.

Di tahun 2000, kira-kira 86,1\% dari 240.271.522 penduduk di Indonesia adalah pemeluk Islam, 8,7\% Protestan, 3\% Katolik, 1,8\% Hindu, dan 0,4\% kepercayaan lainnya (Siti Fatimah, dkk, 2016: 61). Kemajemukan agama tersebut merupakan suatu hal yang sensitif yang bisa menimbulkan ketidakrukunan dan pecahnya persatuan dan kesatuan bangsa Indonesia yang dapat mengakibatkan tidak berhasilnya pembangunan Nasional. Oleh karena itu keenam umat beragama ini hendaknya benar-benar menyadari bahwa Tri Kerukunan Hidup Beragama sungguh sangat penting dan bermanfaat dalam upaya kita mewujudkan persatuan dan kesatuan bangsa. Bentuk Tri Kerukunan Hidup Beragama yang telah disepakati, yakni : (1) Kerukunan intern umat beragama, (2) Kerukunan antarumat beragama, dan (3) Kerukunan antara umat beragama dengan pemerintah (Oka Diputhera, 2002: 83). 
Kerukunan intern umat beragama merupakan yang cukup peka yang tidak luput dari perpecahan dari intern agama tersebut. Yang perlu kita himbau dan harapkan adalah adanya kerukunan intern umat beragama itu sendiri, karena perpecahan di dalam kalangan umat dalam seagama dapat memicu pada perpecahan persatuan dan kesatuan bangsa. Kerukunan hidup beragama itu sebenarnya tergantung dari kerukunan hidup umat beragama mayoritas. Karena agama dengan jumlah umat terbesar apabila telah hidup rukun dan bersatu padu, maka kerukunan hidup umat beragama serta persatuan dan kesatuan bangsa Indonesia dapat terjamin (Oka Diputhera, 2002: 84).

Banyak agama maupun aliran kepercayaan yang ada di Indonesia, konflik antar agama sering kali tidak terelakkan. Lebih dari itu, kepemimpinan politis Indonesia memainkan peranan penting dalam hubungan antar kelompok maupun golongan. Program transmigrasi secara tidak langsung telah menyebabkan sejumlah konflik di wilayah timur Indonesia. Pada zaman Orde Lama untuk mempertemukan pemimpin umat beragama Islam, Kristen, dan Katolik ternyata tidak mudah bahkan dapat dokatakan gagal. Hal ini disebabkan antara umat Islam, Kristen dan Katolik saling curiga-mencurigai, dan masing-masing melaksanakan politik praktis. Tetapi dalam zaman Orde Baru, upaya untuk membina kerukunan hidup umat beragama, secara bertahap telah dilakukan dengan melalui dialog, konsultasi, pertemuan silaturahmi dan lain-lain (Oka Diputhera, 2002: 62).

Misalkan pada zaman Menteri Agma Mukti Ali telah diusahakan untuk mengadakan dialog ilmiah tentang kerukunan umat beragama yang diikuti oleh pemimpin dari MUI, PGI, KWI, PHDI, dan WALUBI. Melalui dialog ilmiah tersebut, akhirnya kerukunan hidup umat beragama yang dimaksudkan disini adalah kerukunan yang disebabkan timbulnya rasa kerukunan yang terjadi setelah memahami bahwa semua agama mengajarkan tentang kerukunan hidup bersama.

Pola hubungan agama dan negara di Indonesia nampaknya menjadi problema yang penting untuk ditindak lajuti. Fenomena sosiologis yang sekaligus merupakan indikasi religiusitas multikulturalisme Indonesia tercermin pada Pancasili - sebagai dasar Negara- diletakkannya ungkapan yang bersifat religius "Ketuhanan Yang Maha Esa" pada sila pertamanya. Sila ini mewarai sila-sila lainnya termasuk penjabarannya ke dalam Undang-undang Dasar Negara RI. DI dalam UUD 1945 ayat 1 dan 2 dinyatakan bahwa; pertama, Negara berdasarkan atas Ketuhanan Yang Masa Esa; Kedua, Negara menjamin kemerdekaan tiap-tiap penduduk untuk memeluk agamanya masing-masing dan untuk beribadat menurut agamanya dan kepercayaannya itu (Aksin Wijaya, 2016: 198). 


\section{Daimah}

Sebagai kepanjangan tangan negara dan pemerintah untuk mempertahankan religiusitas multikulturalisme Indonesia maka dibentuklah Kementerian Agama pada tanggal 3 Januari 1946. Peran, fungsi, dan tugasnya secara prinsipil merupakan cerminan dari ideologi dan falsafah negara. Jika negara berideologi Pancasila dan bermotto Bhineka Tunggal Ika (multikulturalisme atau pluralisme) dengan mewadai berbagai etnis, suku, ras, golongan dan sebagainya, maka Kementerian Agama (Kemenag) yang secara struktural konstitusional mengadministrasi keberadaan enam agama yang mencerminkan pengakuan dan penghargaan terhadap pentingnya multikulturalisme dan pluralisme agama. Itu berarti, multikulturalisme dan pluralisme telah menjiwai semangat dan eksistensi Kemenag itu sendiri (Aksin Wijaya, 2016: 199).

Sebagai turunan dari misi dan tugas Kemenag sebagaimana dipaparkan diatas, beberapa langkah strategis dan mendasar yang dilakukan yang sejatinya dilakukan oleh Kementerian Agama bersama masyarakat, sebagaian diantaranya adalah mengadakan program studi agama-agama, dialog antar umat beragama, dan kerja sama antar umat beragama.

\section{a. Studi Agama-agama}

Studi agama-agama diarahkan untuk kepentingan keumatan dalam arti umat harus mengalami dan mendalami agama sendiri dan agama orang lain, juga demi kepentingan kebangsaan dalam arti memperkuat tegaknya pilar-pilar kerukunan antarumat beragama dalam kerangka pembinaan stabilitas dan integritas nasional. Studi agama-agama itu sejatinya diarahkan pada hal-hal fundamental strategis dengan melibatkan mahasiswa dan calon atau pemuka agama-agama (Aksin Wijaya, 2016: 206).

\section{b. Dialog Antar Agama}

Berbeda dengan watak dakwah, didalam dialog antarumat beragama tersimpan semangat dakwah seseorang mempunyai keyakinan akan kebenaran dan keselamatan yang ditawarkan agamanya sendiri, tetepai pada saat yang sama menghargai keberadaan dan keabsahan yang ada pada agama lain. Didalam dialog antar agama, seseorang yang berbeda agama hanya sekedar berkeinginan untuk mengetahui doktrin dan praktik yang diajarkan oleh agama lain (Aksin Wijaya, 2016: 210).

\section{c. Kerjasama Antar Agama}

Ketika masing-masing komunitas agama sudah saling mengetahui dan menghargai perbedaan keyakinan dan kepercayaan agama masing-masing, perlu diadakan tindak lanjutnya ke arah yang lebih konkret yakni kerjasama antarumat beragama untuk hal-hal yang mempunyai 
kesamaan yang dalam Al-Quran disebut "kalimatun sawa". Misalkan kerjasama dalam mengentaskan kemiskinan melalui peciptaan lapangan kerja, membela hak asasi manusia dengan melakukan advokasi terhadap kelompok tertindas, baik yang dialami para penganut agama, orang-orang miskin, kaum perempuan, menolak kekerasan dalam bentuk apapun, dan lain sebagainya (Aksin Wijaya, 2016: 225).

Ide pluralitas dan multikulturalisme juga perlu dipahami sebagai pemahaman untuk mengatasi persoalan ini. Definisi pluralisme agama yang sering disalahpahami maknanya menjadi kontraversi bagi sebagian kalangan, hal ini disebabkan adanya pemaknaan sepihak mengenai definisi pluralisme itu sendiri. Pluralisme agama bukanlah bermaksud untuk menyamakan agama, namun hanya sebatas mutual respect (saling menghormati). Diharapkan masyarakat bisa menerima segala bentuk perbedaan juga hidup berdampingan secara damai. Nilai-nilai kemanusiaan akan lebih diutamakan daripada mempertentangkan perbedaan ideologi atau perbedaan keyakinan. Toleransi antar sesama umat akan bernilai tinggi dan tidak akan mudah menghujat paham. Karena pada substansinya semua agama mengajarkan tentang kebaikan dan moral universal. Keaneragaman merupakan suatu khazanah bangsa Indonesia yang merupakan anugerah dari Tuhan Yang Maha Kuasa dan yang terpenting adalah keutuhan serta kesatuan bangsa yang harus senantiasa terjaga agar bisa memaknai falsafah luhur Pancasila.

\section{Dinamika Kerukunan Umat Beragama di Malaysia}

Malaysia merupakan negara yang kaya akan keragaman pendudukanya. Keragaman ini bisa dilihat dari aspek keimanan, suku, bahasa, dan budaya dengan populasi 23 juta orang yang terdiri dari 200 kelompok etnis yang berbeda. Departemen Statistik Malaysia (2011: 5) melaporkan bahwa penduduk Malaysia pada tahun 2010 diperkirakan sekitar 28,3 juta, di mana orang Malaysia mencapai sekitar 91,8 persen dan sisanya 8,2 persen adalah bukan warga negara. Warga Malaysia terdiri dari kelompok etnis Bumiputera (67,4\%), Cina (24,6\%), India $(7,3 \%)$, dan lain-lain (0,7\%). Warga Malaysia yang mengaku Islam telah mencatat persentase tertinggi; (61,3\%). Sementara itu, umat Buddha berada di tempat kedua $(19,8 \%)$, Kristen (9,2\%), Hindu (6,3\%), dan sisanya berasal dari kelompok agama lain (Aemy Elyani Mat Zain, dkk, Jurnal International Journal of Islamic Thought Vol. 5, 2014: 1).

Malaysia selalu menjadi pusat perhatian karena masyarakatnya yang sangat beragam dan majemuk. Namun, itu juga merupakan tantangan besar bagi Malaysia untuk mempertahankan koeksistensi damai di antara masyarakat multi-agama dan multi-etniknya. "Malaysia Truly Asia" slogan yang diundangkan di seluruh dunia untuk menunjukkan betapa beragam masyarakat Malaysia dan betapa bangganya kita mempertahankan koeksistensi damai. 


\section{Daimah}

Menurut Aemy Elyani Mat Zain menyebutkan bahwa salah satu alternatif untuk menciptakan negara yang lebih damai, dan harmonis, serta komunitas pelengkap dan pemahaman adalah dengan mengadakan dialog antar-agama. Dialog-antar agama telah terjadi secara informal di masyarakat Malaysia, misalnya sosialisasi dan pertemuan antar agama-agama yang berbeda dalam konteks lingkungan, komunitas, pekerja, pendidikan, dan administrasi yang biasanya memicu dialog dengan cara yang tidak direncanakan. Awalnya, komunitas Muslim di Malaysia berpikiran tertutup dan tidak siap untuk berdialog, terutama dialog antaragama (Utusan Malaysia 2008). Karena sikap konservatif dan perasaan tidak nyaman di kalangan Muslim dalam menerima ide dialog antar-agama dibandingkan dengan non-Muslim, pemerintah telah merumuskan dan memperkenalkan dialog antar-agama dengan cara yang lebih terencana untuk organisasi Islam. Sebagai contoh, Departemen Pembangunan Islam Malaysia (JAKIM) telah mengambil peran melaksanakan rencana aksi dan telah lebih jauh memimpin organisasi-organisasi Islam lainnya dalam melakukan kegiatan dialog antaragama di Malaysia (Aemy Elyani Mat Zain, dkk, Jurnal International Journal of Islamic Thought Vol. 5, 2014: 3).

Dalam memperluas dialog antara keyakinan yang berbeda, Malaysia tidak hanya fokus pada orang-orang saja, tetapi kepemimpinan Malaysia juga memainkan peran, di mana Perdana Menteri Malaysia, Najib Tun Razak telah terlibat langsung dengan 'World Interfaith Harmony Week 2012'. Acara ini melibatkan para pemimpin dari berbagai agama, termasuk Islam, dan mereka bertemu, berdiskusi dan berdialog satu sama lain. Dalam pidatonya, ia menyatakan bahwa tujuan dari acara ini adalah untuk menanamkan kesadaran dan pemahaman tersebut di antara para penganut agama di Malaysia (New Straits Times 2012). Selain itu, lembaga non-pemerintah juga peka terhadap kebutuhan dialog antaragama di Malaysia. Berbagai cara dan bentuk dialog antar-agama telah tertanam dalam kegiatan dialog. Beberapa dilakukan dalam bentuk dialog antara wacana agama dan diskusi, beberapa memiliki dialog pada fungsi informal dari perayaan antar agama pada acara perayaan tertentu dari kelompok agama tertentu, dan beberapa telah melakukan dialog antar-agama ketika isu-isu antar agama muncul di antara mereka (Aemy Elyani Mat Zain, dkk, Jurnal International Journal of Islamic Thought Vol. 5, 2014: 4).

Wan Sabri dan Arfah yang menyebutkan empat bentuk dan model dialog antar-agama, yang telah diklasifikasikan oleh peneliti asing sebagai: a) penyelidikan kolektif, b) pendidikan kritis-dialogis, c) resolusi konflik dan pembangunan perdamaian, dan d) pembangunan komunitas dan aksi sosial. Mereka menyatakan bahwa secara umum, dialog antar-agama di Malaysia dapat terjadi sebagai empat model dialog, misalnya dialog penyelidikan kolektif 
yang dilakukan oleh INSAF, yang melibatkan pertemuan bulanan mereka yang terbuka bagi anggota berbagai latar belakang agama, etnis, dan budaya (Wan Sabri Wan Yusuf \& Arfah Ab Majid, Jurnal GJAT Vol. 2, 2012: 10).

\section{Urgensi Perempuan Dalam Membangun Kerukunan Umat Beragama}

Pada dasarnya setiap agama memiliki konsep cita-cita yang sama, yakni kedamaian, kerukunan dan kebahagiaan atau kesempurnaan. Idealnya tidak perlu muncul persoalan atau konflik apabila masing-masing secara inklusif mematuhi doktrin tekstual ajaran agamanya masing-masing. Namun apabila dikaitkan dengan tuntunan aktual masing-masing agama maka akan terjadi pendekatan kontekstual yang sering memunculkan aneka ragam penafsiran yang dapat berbenturan anatara yang satu dengan yang lain. Perbedaan penafsiran yang saling berbenturan itulah yang kemudian menjadi sikap kurang empati dan simpati, eksklusif, dan melahirkan prasangka yang buruk kepada yang lain.

\section{1) Peran Perempuan dalam Keluarga}

Keluarga merupakan suatu lembaga sosial yang paling besar perannya bagi kesejahteraan sosial dan kelestarian anggota-anggotanya terutama anak-anaknya. Keluarga merupakan lingkungan sosial yang terpenting bagi perkembangan dan pembentukan pribadi anak dan merupakan wadah tempat bimbingan dan latihan anak sejak kehidupan mereka yang sangat muda sehingga dapat menempuh kehidupannya dengan baik kelak. Keberhasilan pendidikan anak-anak merupakan tanggung jawab Ibu walaupun tentunya keikut-sertaan seorang Ayah juga tidak dapat diabaikan. Ibu memainkan peran yang penting dalam mendidik anakanaknya, terutama pada masa balita. Pendidikan di sini tidak hanya dalam pengertian yang sempit. Pendidikan dalam keluarga dapat berarti luas berupa pendidikan iman, moral, fisik/ jasmani, intelektual, psikologis, sosial, dan pendidikan seksual.

Peranan perempuan sebagai Ibu di dalam mendidik anak dibedakan menjadi tiga tugas penting, yaitu :

\section{1) Ibu sebagai sumber pemenuhan kebutuhan anak}

Bagi anak, terutama pada saat anak di dalam ketergantungan total terhadap ibunya, yang akan tetap berlangsung sampai periode anak sekolah, bahkan sampai menjelang dewasa. Ibu perlu menyediakan waktu yang cukup untuk selalu berinteraksi maupun berkomunikasi secara terbuka dengan anaknya. Pada dasarnya kebutuhan seseorang meliputi kebutuhan fisik, psikis, sosial dan spiritual. Kebutuhan fisik merupakan ke- 


\section{Daimah}

butuhan makan, minum, pakaian, tempat tinggal, dan lain sebagainya. Kebutuhan psikis meliputi kebutuhan akan kasih sayang, rasa aman, diterima dan dihargai.

Sedang kebutuhan sosial akan diperoleh anak dari kelompok di luar lingkungan keluarganya. Dalam pemenuhan kebutuhan ini, ibu hendaknya memberi kesempatan bagi anak untuk bersosialisasi dengan teman sebayanya. Kebutuhan spiritual, adalah pendidikan yang menjadikan anak mengerti kewajiban kepada Allah, kepada Rasul-Nya, orang tuanya dan sesama saudaranya (Andi Bahri S, Jurnal Al-Maiyyah Vol. 8, 2015: 190). Disini Ibu memberikan pengetahuan pertama tentang kebutuhan spiritual anak yang nantinya akan menjadikan landasan bagi anak untuk bersosial dalam kehidupan masyarakat.

\section{2) Ibu sebagai teladan atau "model" peniruan anak}

Dalam mendidik anak seorang ibu harus mampu menjadi teladan bagi anak-anaknya. Mengingat bahwa perilaku orangtua khususnya ibu akan ditiru yang kemudian akan dijadikan panduan dalam perlaku anak, maka ibu harus mampu menjadi teladan bagi anak-anaknya. Sejak anak lahir dari Rahim seorang ibu, maka ibulah yang banyak mewarnai dan mempengaruhi perkembangan pribadi, perilaku, dan akhlaq anak. Untuk membentuk perilaku anak yang baik tidak hanya melalui bil lisan tetapi juga dengan bil hal yaitu mendidik anak lewat tingkah laku.

Sejak lahir ia akan selalu melihat dan mengamati gerak gerik atau tingkah laku ibunya. Dari tingkah laku ibunya itulah anak akan senantiasa melihat dan meniru yang kemudian diambil, dimiliki, dan diterapkan dalam kehidupannya (Andi Bahri S, Jurnal Al-Maiyyah Vol. 8, 2015: 192). Jika seorang ibu berperilaku social dengan baik dalam kehidupan masyarakat beragama tanpa membedakan antar suku, agama, dan ras, seorang anak juga akan meneladani perilaku tersebut, begitu juga sebaliknya.

\section{3) Ibu sebagai pemberi stimulasi bagi perkembangan anak}

Perlu diketahui bahwa pada waktu kelahirannya, pertumbuhan berbagai organ belum sepenuhnya lengkap. Perkembangan dari organ-organ ini sangat ditentukan oleh rangsang yang diterima anak dari ibunya.

Rangsangan yang diberikan oleh ibu, akan memperkaya pengalaman dan mempunyai pengaruh yang besar bagi perkembangan kognitif anak. Bila pada bulan-bulan pertama anak kurang mendapatkan stimulus visual maka perhatian terhadap lingkungan sekitar kurang. Stimulus verbal dari ibu akan sangat memperkaya kemampuan bahasa 
anak. Kesediaan ibu untuk berbicara dengan anaknya akan mengembangkan proses bicara anak. Jadi perkembangan mental anak akan sangat ditentukan oleh seberapa rangsang yang diberikan ibu terhadap anaknya.

Rangsangan dapat berupa cerita-cerita, macam-macam alat permainan yang edukatif maupun kesempatan untuk rekreasi yang dapat memperkaya pengalamannya (Andi Bahri S, Jurnal Al-Maiyyah Vol. 8, 2015: 194). Dalam hal ini, peran seorang Ibu memberikan visual keberagaman dalam diri anak. Memberikan bekal pengetahuan anak tentang pluralitas ras, suku dan agama. Sehingga saat dewasa kelak, anak akan berprasangka bahwa pluralitas itu adalah suatu rahmat bukan perpecahan.

Dari apa yang dikemukakan diatas jelaslah bahwa kunci keberhasilan seorang anak dalam memahami kehidupan beragamanya sangat bergantung pada seorang perempuan, yaitu Ibu. Sikap Ibu yang toleran terhadap sesama umat beragama, memberikan kesempatan pada anak untuk memperkaya pengalaman, menerima, menghargai dan dapat menjadi teladan yang positif bagi anaknya, akan besar pengaruhnya terhadap perkembangan pribadi anak. Dengan demikian dapat dikatakan bahwa salah satu faktor yang mempengaruhi sikap sosial beragama seorang anak akan diperoleh dari interaksi yang dilakukan ibu dan anak.

\section{2) Peran Perempuan dalam Keluarga}

Dewasa ini pemberdayaan (empowerment) perempuan dan kemitrasejajaran laki-laki dan perempuan dalam berbagai dimensi kehidupan mendapat perhatian secara global dikalangan pemerhati perempuan dan pemerhari masalah pembangunan. Hal ini disebabkan oleh adanya kenyataan perihal posisi perempuan yang subordinasi dan terdiskriminasi dari laki-laki dari berbagai kelompok masyarakat, termasuk pada bidang sosial. Secara umum kondisi perempuan mengalami perubahan sebagaimana tampak dalam laporan statistik tentang peningkatan pendidikan dan partisipasi perempuan dalam sektor publik.

Terbukti dengan penghargaan Agen Perubahan PBB yang diraih Menlu Retno Marsudi dalam acara UN Women: Agent of Change, Builder of Peace with Minister of Foreign Affairs. Dalam pidatonya, Retno menyatakan bahwa perempuan merupak agen perubahan untuk perdamaian, dan ada tiga aspek yang membuktikannya, Pertama, bahwa perempuan secara natural merupakan agen perdamaian. Perempuan diberikan insting melindungi apa yang ada. Hal ini merupakan sifat natural pada setiap perempuan untuk melindungi keluarganya. Kedua, Perempuan secara alami dapat dipercaya. Hal tersebut dibuktikan dengan kepercayaan 


\section{Daimah}

yang diterima perempuan dari anak-anaknya. Dan ketiga, wanita sebagai agen alami untuk mengajarkan toleransi. Untuk mencapai kesetaraan gender, perempuan merupakan penggerak pertama. Dengan mengajarkan toleransi pada anak dari rumah, hal itu bisa dibawa ke dunia luar (Marcheilla Ariesta, http://internasional.metrotvnews.com/asia/4ba7YA3K-perempuanadalah-agen-perubahan-untuk-perdamaian diakses pada Jumat, 28 September 2018).

Adapun usaha yang dapat dilakukan perempuan dalam mewujudkan perdamaian dalam kehidupan sosial beragama salah satunya adalah dengan mengembangkan wacana dialogis dalam pluralisme keberagamaan dengan membentuk komunitas perempuan lintas iman. Sebagaimana di Yogyakarta (Indonesia), telah berdiri sebuah komunitas perempuan Srikandi Lintas Iman yang bertujuan sebagai wadah untuk perempuan lintas agama untuk saling mengenal, bersama, membangun persahabatan kemudian menjalin kerjasama (Wiwin Siti Aminah Rahmawati, Wawancara Pribadi, 2018:_). Berbeda dengan komunitas perempuan lainnya, Srikandi Lintas Iman aktif dalam melakukan dialog lintas iman dan berbagai kegiatan lintas iman sebagai wujud kerukunan umat beragama di Indonesia. Kegiatan yang telah dilakukan misalnya mengadakan kunjungan ke beberapa tempat ibadah, ikut dalam partisipasi bakti sosial yang dilakukan komunitas agama tertentu, mengadakan dialog atau seminar bertemakan toleransi dan pluralitas dalam masyarakat, menjalin kerja sama dengan komunitas-komunitas Lintas Iman lainnya dan masih banyak lagi kegiatan lainnya.

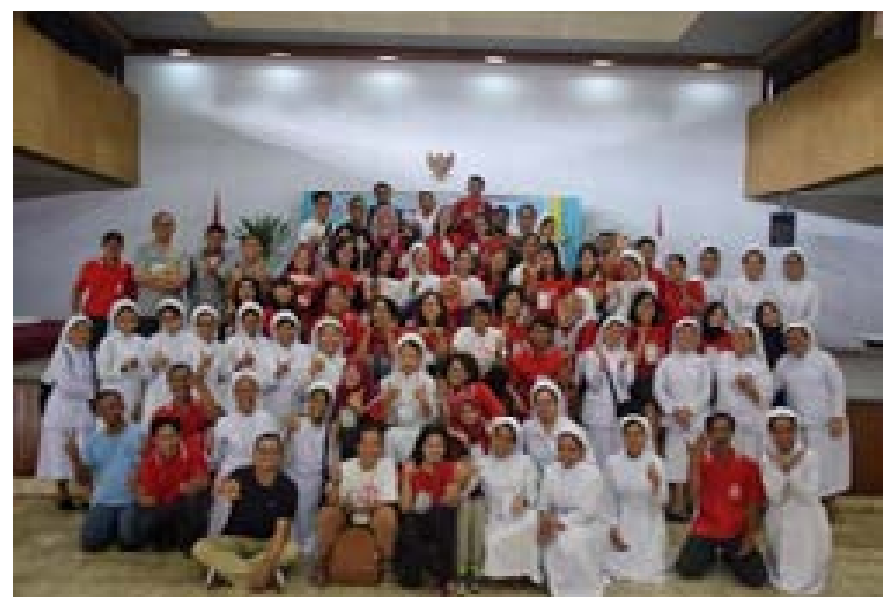

\section{Gambar 1. Kegiatan Srawung \\ Bocah Lintas Iman yang diselenggarakan Susteran CB Bekerjasama dengan Komunitas Srikandi}

Srikandi Lintas Iman dideklarasikan sebagai komunitas perempuan lintas iman yang diharapkan aktif melakukan dialog dan peduli pada persoalan sosial, terutama persoalan perempuan dan anak. Dengan deklarasi tersebut, diharapkan tindak lanjut revitalisasi pengelolaan keberagaman, dapat diambil dan diperankan oleh perempuan sebagai aktor perubahan (Wiwin Siti Aminah Rohmawati, diakses melalui https://www.srikandilintasiman. 
org/profil-srikandi-lintas-iman-yogyakarta/ pada 28 September 2018).

Senada dengan di Indonesia, Malaysia juga memiliki lembaga yang berkonsentrasi terhadap pluralitas beragama, salah satunya adalah "The Malaysian Interfaith Network" (MIN). The Malaysian Interfaith Network (MIN) dibentuk pada 15 Februari 2003. Jaringan antaragama bertujuan untuk menciptakan masyarakat yang lebih harmonis dan damai di Malaysia yang multi-rasial dan multi-agama. MIN terdiri dari 30 peserta dari berbagai agama, mulai dari kelompok Islam hingga Budha dan Hindu. Semua kelompok ini memiliki tujuan yang sama yaitu untuk mempromosikan kesatuan agama di Malaysia. Lembaga surat kabar nasional seperti The Star dan The New Straits Times juga merupakan peserta aktif dalam jaringan ini. Agenda utama di balik penciptaan MIN adalah bertindak sebagai platform utama komunikasi, inisiatif dan tindakan untuk berbagai organisasi ini (_ diakses melalui http://pluralism.org/ profile/the-malaysian-interfaith-network-min/ pada 30 September 2018).

Hal tersebut membuktikan bahwa perempuan sebagai agen sosial juga mampu melakukan kegiatan-kegiatan lintas agama yang berpotensi dapat membangun kerukunan umat beragama.

\section{Kesimpulan}

Kerukunan antar umat beragama adalah cara atau sarana untuk mempertemukan, mengatur hubungan luar antara orang yang tidak seagama atau antar golongan umat beragama dalam kehidupan sosial kemasyarakatan. Mewujudkan kerukunan dalam keberagaman bukanlah hal yang mudah. Butuh adanya suatu usaha komitmen kuat, karena hal ini sesungguhnya keberagaman merupakan awal mulanya konflik sosial. Penyebab konflik sosial tersebut sebagaimana yang diuraikan oleh Puslitbang Kehidupan Keagamaan Badan Litbang dan Diklat Departemen Agama meliputi: 1) pendirian rumah ibadah, 2) penyiaran agama, 3) bantuan luar negeri, 4) bantuan agama, 5) perayaan hari besar keagamaan, 6) penodaan agama, 7) kegiatan aliran sempalan, dan 8) aspek non agama yang mempengaruhi.

Dalam hal ini, perempuan sebagai anggota masyarakat dan keluarga memiliki potensi sebagai agen dalam pembentukan kerukunan umat beragama. Peran domestik perempuan mampu memberikan stimulus positif terhadap masyarakat didalam keluarganya sekaligus menjadi teladan dalam menyikapi keberagaman di masyarakat. Kemudian di Indonesia dan Malaysia sebagai negara multikultural seherusnya memberikan ruang penuh kepada perempuan untuk berpartisipasi dalam kegiatan publik. Peran publik perempuan dapat terlibat dalam kegiatan keorganisasian independen maupun komunitas politik masyarakat yang diselenggarakan oleh pemerintah. 


\section{Daimah}

\section{Daftar Pustaka}

Aemy Elyani Mat Zain, dkk, Inter-Religious Dialogue : The Perspective of Malaysian Contemporary Muslim Thinkers, dalam Jurnal International Journal of Islamic Thought Vol 5 : June 2014.

Aksin Wijaya, Visi Pluralisme-Humanis Islam Faisal Ismail, Yogyakarta : Dialektika, 2016.

Andi Bahri S, Perempuan dalam Islam: Mensinergikan antara Peran Sosial dan Peran Rumah Tangga, dalam Jurnal Al-Maiyyah, Vol 8 No. 2 Juli-Desember 2015.

Ibnu Rusydi, Makna Kerukunan Antar Umat Beragama dalam Konteks KeIslaman dan KeIndonesiaan, dalam Jurnal Al-Afkar Vol. 1 No 1 January 2019.

Ihsan Ali Fauzi, dkk, Kebebasan, Toleransi dan Terorisme: Riset dan Kebijakan Agama di Indonesia, (Jakarta: Yayasan Paramadina, 2017).

Imron Rosyidi, Pendidikan Berparadigma Inklusif, (Malang : UIN Malang Press, 2009).

Nurcholis Madjid, Pluralitas Agama : Kerukunan dalam Beragama, (Jakarta : Kompas, 2001).

Marcheilla Ariesta, http://internasional.metrotvnews.com/asia/4ba7YA3K-perempuanadalah-agen-perubahan-untuk-perdamaian diakses pada Jumat, 28 September 2018 pukul 12.29 wib.

Oka Diputhera, Kerukunan Umat Beragama Pilar Utama Kerukunan Berbangsa, (Jakarta :BPK Gunung Mulia, 2002).

Peraturan Bersama Menteri Agama dan Menteri Dalam Negeri (PMB) No 8 dan 9 tahun 2006 pasal 1.

Siti Fatimah, dkk, Gender dan Pendidikan Multikultural, (Jakarta : Kencana, 2016).

Wan Sabri Wan Yusof dan Arfah Ab Majid, Inter-Religious Dialogue Models in Malaysia, dalam Jurnal GJAT Vol 2 Issue 1 June 2012

Wiwin Siti Aminah Rohmawati, https://www.srikandilintasiman.org/profil-srikandi-lintasiman-yogyakarta/ diakses pada Jumat, 28 September 2018 pukul 21.47 wib.

_, http://pluralism.org/profile/the-malaysian-interfaith-network-min/ diakses pada Minggu, 30 September 2018 pukul 20.52 wib. 